\title{
INFORMATION SYSTEMS OUTSOURCING REASONS AND RISKS: A NEW
}

\begin{abstract}
ASSESSMENT
Reyes Gonzalez is a Senior Lecturer in Business Management and Information Systems at the University of Alicante. Her current research interests are Information Systems Management, EBusiness and Outsourcing Processes. She has published articles in several journals, e.g. Business Process Management Journal, Information Processing and Management, Information and Management, Information Technology and People, International Journal of Information Management, Information Management \& Computer Security, Industrial Management \& Data Systems, Journal of European Industrial Training, Logistics Information Management, Total Quality Management, and The International Journal of Educational Management.
\end{abstract}

Jose Gasco is a Senior Lecturer in Business Management and Human Resources at the University of Alicante. His current research interests include Human Resources and Information Systems Outsourcing. He has published articles in several journals, namely, Revue Internationale P.M.E., Direction et Gestion des Entreprises, Corporate Communications: an International Journal, The International Journal of Public Sector Management, Business Process Management Journal, Business Process Management Journal, Information Processing and Management, International Journal of Information Management, Information Management \& Computer Security, Industrial Management \& Data Systems, Total Quality Management, Journal of European Industrial Training, Information Technology and People, and Logistics Information Management.

Juan Llopis is Dean of the Faculty of Economics and Professor of Business Organisation at the University of Alicante. Among his current research lines stand out Organisational Culture, Human Resources, Quality Management, and Information Systems Management. He has published articles in journals like Information and Management, Total Quality Management, Journal of High Technology Management Research, Corporate Communications: An International Journal, Information Technology and People, Business Process Management Journal, Information Processing and Management, Journal of European Industrial Training, Logistics Information Management Journal, International Journal of Information Management, Information Management \& Computer Security, Industrial Management \& Data Systems and International Journal of Value-Based Management.

\section{CORRESPONDING AUTHOR}

Reyes Gonzalez. Department of Business Organisation. University of Alicante. Carretera San Vicente-Alicante. Zip Code: 03080. Alicante. SPAIN. Telephone and Fax: 349659036 06. E-mail: mr.gonzalez@ua.es. 


\section{INFORMATION SYSTEMS OUTSOURCING REASONS AND RISKS: A NEW}

\section{ASSESSMENT ${ }^{1}$}

\section{PAPER TYPE Research Paper}

\section{ABSTRACT}

Purpose- Outsourcing is currently going through a stage of unstoppable growth. This paper makes a proposal about the main reasons which may lead firms to adopt Outsourcing in Information Systems services. It will equally analyse the potential risks that IS clients are likely to face. An additional objective is to assess these reasons and risks in the case of large Spanish firms, while simultaneously examining their evolution over time. This study of outsourcing reasons and risks has been carried out from the client's perspective.

Desing/methodology/approach- In order to achieve these aims, a questionnaire was administered to the IS managers of the largest Spanish firms.

Findings- Outsourcing gives the organisations the opportunity to have better IS services and the possibility to achieve technological improvements and, although cost savings in staff and technology are generally seen as very important, they do not emerge as priority reasons for outsourcing in the present study. Regarding risks, they are mainly associated with providers, with great concern being expressed about the lack of qualification among their providers' staff, the potential lack of compliance with contracts, and the inability to adapt to the New Technologies. Originality/Value- An important contribution made by this study is not only the specification of those reasons and risks but also the fact that they are considered important by the firms interviewed.

Keywords- Information Systems, Outsourcing, Reasons, Risks, Survey, Spain.

\footnotetext{
${ }^{1}$ The authors would like to thank the editor and two anonymous reviewers for all their suggestions.
} 


\section{INFORMATION SYSTEMS OUTSOURCING REASONS AND RISKS: A NEW}

\section{ASSESSMENT}

\section{INTRODUCTION}

A wide range of facts and figures confirm the status of IS (Information Systems) or IT (Information Technologies) outsourcing as a growing, increasingly global phenomenon in the new millennium. Thus, the IT market moved ca. 185 billion $€$ worldwide in 2005 (IDATE Foundation, 2005). Forrester estimates that the value of the world's outsourcing market is 120 billion \$ per year (Takahashi and Sayer, 2007) and predicts that European firms will increase the expenses derived from outsourcing in 2008. The Gartner Group expects the outsourcing market to grow from 180.5 billion $\$$ in 2003 to 253.1 billion $\$$ in 2008 . $87 \%$ of the companies interviewed by KPMG plan to maintain —or increase - their current outsourcing level (ZDNet, 2007), since $42 \%$ of them thought that their outsourcing contracts had definitely improved their financial performance, and another $27 \%$ stated that outsourcing had enhanced their competitiveness (Khan, 2007; KPMG, 2007). Although the numerical estimates of outsourcing figures vary across sources, no one can deny their magnitude or the expectations for growth in the coming years.

In the light of the above, the present study has as its main aim to propose a set of outsourcing reasons and risks, and to assess their importance and evolution over time within the context of the largest Spanish firms. For that purpose, a previous examination must be made of the position occupied by those firms in relation to IS outsourcing. The paper is structured as follows: after a review of the literature devoted to this topic which will help to identify the reasons and risks associated with IS outsourcing, there is a section illustrating the case of some large Spanish firms 
that are well-known for outsourcing its IT; then a presentation will be made of the methodology and the results of the empirical work, along with a summary of the main conclusions.

\section{IS OUTSOURCING REASONS AND RISKS: A LITERATURE REVIEW}

Quite a few authors have researched into the possible reasons leading firms to outsource their IS and into the multiple risks that this decision involves. All their studies have served as a reference to propose a number of reasons and risks that will later be evaluated during the empirical work.

\section{IS Outsourcing Reasons}

Focusing on Strategic Issues. Market forces are somehow driving firms to outsource everything but the core business (Gupta and Gupta, 1992). And outsourcing makes it easier for these firms to focus on their basic competences (Grover, Cheon and Teng, 1996; Hayes, Hunton and Reck, 2000; Lacity, Hirschheim and Willcocks, 1994; Smith, Mitra and Narasimhan, 1998; Willcocks, Feeny and Olson, 2006). In the computer area this liberates line managers — who do not have to coordinate with a large IS department - thus simplifying the organisation. Likewise, the outsourcing of the most routine activities allows computer experts to dedicate their time to key IS activities (Grover, Cheon and Teng, 1994).

Increasing Flexibility. The great change experienced by technology in recent years gives many firms a chance to obtain a considerable advantage from outsourcing, as they will prevent becoming technologically obsolete without having to make large investments in technology. Business organisations can increase their flexibility through a continuous redesign of their contracts that will allow them to meet their information needs at any given time (Clark, Zmud and McCray, 1995). Outsourcing additionally provides a large degree of flexibility in the utilisation of IT resources and makes it easier to face business level volatility, as the provider is 
left to deal with fluctuations in IT workloads (Jurison, 1995). Firms can equally use outsourcing as a strategy to achieve flexibility during a restructuring or reorganisation process.

Outsourcing can Improve the Quality delivered by IS services. The provider can access more advanced technologies and count on more motivated staff and better management systems in order to be able to achieve a better service coordination or control, or, simply, is more strongly committed than the internal staff to make the alliance with the client work properly (Clark, Zmud and McCray, 1995). At least in theory, firms outsource so that they can have at their disposal high-quality IT services and knowledge (Baldwing, Irani and Love 2001; Lee, Huynh and Hirschheim, 2008).

Outsourcing very often serves to Get Rid of Routine Tasks — which are very time-consumingin IT management (Grover, Cheong and Teng, 1994, 1996; Hayes, Hunton and Reck, 2000; Lacity and Hirschheim, 1993a). Also, if the IS function is seen as something difficult to manage —often regarded by the top management as a 'headache'- (Lacity, Hirschheim and Willcocks, 1994), outsourcing can remove or minimise a function that is considered clearly problematic (Jurison, 1995, McFarlan and Nolan, 1995).

Facilitating Access to Technology. Outsourcing brings client firms advantages related to technology (Jurison, 1995), as these business organisations can have access to specialised, stateof-the-art technology which is supposedly supplied to them by the provider. On the other hand, the efficient use of outsourcing will most probably reduce the need to make investments in mature technology, simultaneously increasing the availability of resources related to new technologies for the client (Clark, Zmud and McCray, 1995). Additionally, the most 'timid' organisations — which prefer to wait and see what happens with state-of-the-art technologymay resort to outsourcing as a way to minimise the risks incurred if the technology used is not the 
most appropriate (Gupta and Gupta, 1992). In this respect, outsourcing is likely to emerge as a way to experiment with new technologies (Baldwing, Irani and Love, 2001).

Reducing the Risk of Obsolescence. It is precisely the fast pace of change in the field of technology that places firms in front of a dilemma: either making investments on new technologies very often or working with very mature technology. This problem can equally be minimised with technological outsourcing, since the technology accessed by the client is owned by the provider, which means that this risk is assumed by the latter and not by the former (Clark, Zmud and McCray, 1995; Grover, Cheon and Teng, 1994, 1996). Firms can increase their level of flexibility through a process of continuous redesign of the contracts that will help them to cover their information requirements (Hayes, Hunton and Reck, 2000).

Saving Staff Costs. Outsourcing paves the way to a more specialised IT management, as the provider firm finds itself in a better position to select, train and manage its technological staff; in this way, clients can have at their disposal high-level specialists without them having to be permanent members of their staff (Alner, 2001; Ang and Straub, 1998). Clients have in mind a staff reduction which will mean significant cost savings. Computer work is additionally characterised by the deterioration of knowledge and, particularly, by the shortage of specific knowledge. The ability of firms to identify and acquire the IS knowledge required is very important too. In these circumstances, the effort to retain a permanent workforce with a highlevel, up-to-date training is likely to end up becoming too expensive for many companies (Slaughter and Ang, 1996, Olson, 2007).

It helps to Have Alternatives to the IS staff. This reason is closely related to the above-mentioned increase in IS management flexibility. It is undeniable that, thanks to outsourcing, a firm does not have to depend exclusively on its internal IS resources (Claver et al., 2002) 
Saving Technology Costs. Service providers are exposed to a wider variety of problems and experiences associated with IS, which is why a greater volume of knowledge and skills can be obtained that will help to solve these problems. Likewise, service providers dedicate all their capacity to the provision of IS services, as a result of which greater economies of scale and scope can be obtained (Smith, Mitra and Narashimhan, 1998). It is assumed that part of these economies are transferred to the client through lower prices in the achievement of the same services through outsourcing and through the work of the IS internal department (Hayes, Hunton and Reck, 2000). Outsourcing equally makes it possible to turn fixed costs (to maintain an IS department) into variable ones (depending on client needs) and, if the contract has been properly designed, into predictable costs (Grover, Cheon and Teng, 1994, 1996; McFarlan and Nolan, 1995). What is more, outsourcing contracts will probably mean an injection of liquidity for the client firm when it transfers software licenses and staff to the provider (Alner, 2001).

Following the fashion. This last argument is not a trivial one (Lacity and Hirschheim, 1993b; Loh and Venkatraman, 1992, Udo, 2000); firms decide to adopt outsourcing in order to copy the success of other organisations that have already outsourced (Lacity, Hirschheim and Willcoks, 1994).

\section{IS Otsourcing Risks}

Provider Staff Qualification. Although outsourcing theoretically facilitates the access to the technical knowledge and expertise of IS specialists, it very often happens that the outsourcing firm is supported by the same staff as before (Fowler and Jeffs, 1998; Glass, 1996; Tafti, 2005), because that staff has been transferred from the client firm to the service provider. Lacity and Hirschheim (1993b) warn that many of the firms which decide to outsource feel that they have lost business 
knowledge and experience, because after signing a contract, providers send their most highly qualified workers to achieve new clients in other firms within the sector.

Lack of Compliance with the Contract by the Provider. When an agent performs a task for a principal, the latter always faces the risk that the agent might not carry out the task as expected or that the agent might pay less attention and monitor the process less closely than the principal would have done (Clark, Zmud and McCray, 1995). Additionally, in the case of IS outsourcing, client needs may not be properly met, or priorities may be erroneously established, because the provider does not quite understand what the business is all about (Martinsons, 1993).

Problems are likely to arise in relation to the Dependence generated by this service. Firms have difficulty in quantifying and defining their needs in terms of information services, which additionally tend to evolve over time. Therefore, if not all the services have been agreed in the original contract, an extra fee will be applied, thus increasing the total costs (Fowler and Jeffs, 1998). This is why Lacity and Hirschheim (1993b) claim that external providers are not strategic partners, since the interest in benefits is not a shared one - when clients' costs grow, so do providers' benefits.

Loss of Technical Knowledge. When a service is outsourced, clients gradually lose their understanding of the service over time. Even if the provider delivers innovative services to the client, a large proportion of the new knowledge required remains in the hands of the provider and cannot be transferred to the client. What is more serious, the firm may lose its capacity to stay up to date with the technological breakthroughs (Clark, Zmud and McCray, 1995). Furthermore, the innovation capability of the firm itself can be reduced, since every innovation requires a sufficient availability of technical and economic resources, something that is not precisely favoured by outsourcing (Earl, 1996). 
Another risk is the Provider's inability to adapt to the New Technologies. It was mentioned above that one of the advantages derived from outsourcing is the possibility to access state-of-the-art technology, but this is not always the case. If providers do not identify clear benefits in the incorporation of new technologies, they may be reluctant to adopt them, their main concern being to exploit to the full the service that they already offer. What is more, if the contract does not include a clause specifically devoted to technological evolution, the latter will most probably not be completed (Glass, 1996).

Hidden Costs. Among these stand out the following (Willcocks, Lacity and Fitzgerald, 1995; Barthélemy, 2001; Whitten and Wakefield, 2006): a) Search for vendors and hiring; b) Transition costs - the time that internal employees spend helping the outsourcing vendor is a transition cost. The costs resulting from the interruptions and from the lack of skill on the part of the vendor to react in a fast, appropriate way, as the IS internal department did at the beginning of the contract term, are transition costs as well; c) Costs linked to provider control and coordination; d) Transition costs after outsourcing —when the outsourcing contract expires and the client firm decides to perform its IT activities internally again or change its provider.

Unclear Cost-Benefit Relationship. Taking into account all the relevant outsourcing factors and trying to translate them into monetary terms is no easy task - for instance, how to value the potentially better service delivered by the provider or how to measure the consequences derived from a poor quality service on the part of the provider (Gupta and Gupta, 1992). Faced with these difficulties, numerous firms admit that they base their decision to outsource exclusively on the explicit costs generated, leaving aside both the tacit costs and the profits (Clark, Zmud and McCray, 1995). 
Possible Security problems deserve to be mentioned. They are important when a provider attends to several direct competitors, which is why the confidentiality for the information related to all of them must be strictly kept (Grover, Cheon and Teng, 1994; Lacity and Hirschheim, 1993a; Alner, 2001). Security in the IS externalised services will depend on the provider firm and, therefore, a negotiation must take place within the framework of the outsourcing contract for the purpose of establishing policies and procedures to ensure that IS security aims (effectiveness, efficiency, adequacy, integrity, validity, authorisation and privacy) continue to be achieved (Fink, 1994).

Taking all this into account, it is hardly surprising to check that many firms fear the Irreversibility of the Decision to outsource IS, especially if users have got rid of the technical and human infrastructure needed to reconstruct their IS 'in house' (Barthélemy, 2001; Fowler and Jeffs, 1998). There are three reasons for this irreversibility, namely: the high costs involved in the reconstruction of the IS department, the difficulty to attract the necessary staff, and the time required.

Outsourcing generates various Staff Problems, as workers face an uncertain situation which provokes anxiety, low morale, and a feeling of insecurity which can lead to a decrease in their productivity levels during the period that precedes the signature of the contract, and even after the contract has been signed (Palvia, 1995). When only a part of the staff is transferred, it is easy to detect lack of motivation among the employees who stay in the client firm. These professionals may even feel offended because it seems to them that they are not considered good enough to form part of a specialised firm like a computer service provider (Willcocks and Fitzgerald, 1996). Those who remain in the firm can change their responsibilities, and even their status, and very often perform new tasks to which they are not accustomed. This is logical, since the IS department has to be reorganised. The employees who are transferred from one firm to another may go through a number of changes ranging from those affecting their seniority or any beneficial conditions that they 
might have in their previous company to those associated with the need to adapt to a new corporate culture.

Many firms thus fear a Possible Opposition of their Staff to the outsourcing decision, which poses a threat to their job (Grover, Cheon and Teng, 1994; Claver et al., 2002; Brook, 2006), this being a risk that becomes even greater in the case of global outsourcing.

\section{OUTSOURCING IN LARGE SPANISH FIRMS}

In the Spanish area, there are some large firms that are traditionally recognized for outsourcing the IS function. For example, Endesa has entrusted its IT management in Spain and Latin America to IBM for over a decade. Recently - December 2008- this firm has firmed a contract with IBM with a value of 360 million euros for seven years. In this way Endesa wants to cover some objectives like having a unified model to manage technology in all the countries, and to increase the security levels of IT (IBM, 2009; Techweek, 2009-a). RACC (Real Automobile Club of Catalonia) is an insurance company, especialized in the automotive sector, with more than a million of associates in Spain. The outsourcing of IT is for this company a way to answer to the technological needs in the organization with services of high quality. For this reason RACC has signed with IBM a contract at the end of 2008, which involves a five year period and which is valued in 13 million euros (IBM, 2008; Computerworld, 2009). Caixa Galicia has signed in 2009 a contract with BT Spain (valued in 26 million euros and duration of five years). This financial firm has engaged in this outsourcing contract to control costs in communications and, at the same time, to innovate its technology (Techweek, 2009b). Another example is represented by the Spanish rail transport company (RENFE), which has outsourced is IT to HP during three years (Techweek, 2009c), in an effort to modernize its technological infrastructures, control costs and 
get flexibility in its technologies. One of the important points in this contract is to guarantee the continuity of the service.

These are just some examples of large Spanish firms that have outsourced, but now we are going to enter in the field study that we have carried out to understand which are the main reasons and risks that large Spanish firms consider when they are outsourcing IT.

\section{METHODOLOGY}

We have focused in large firms based on the assumption that the largest firms are also the most prone to outsource. The directory Las 5.000 Mayores Empresas [The 5,000 largest firms] of the Actualidad Económica magazine, Duns and Bradstreet's 50.000 Principales Empresas Españolas [50,000 main Spanish firms] and $\mathrm{SABI}^{2}$ served to select the study population. 893 of the 5,000 firms with the highest turnover appearing on the first database were discarded, because their addresses and telephone numbers coincided with those of other organisations, which suggested that they were affiliate or subsidiary companies.

The remaining 4,107 firms received a questionnaire, along with a stamped addressed envelope for the questionnaire to be returned. The questionnaire is largely based on a previous one (Gonzalez, Gasco and Llopis, 2005a, 2005b) prepared by the same authors which, the same as this one, was constructed taking the literature on the topic as a reference. Furthermore, some experts in IS Management analysed the questionnaire. Only 6 of the 26 questions included in the final questionnaire have been used in the present paper. Table 1 shows the measures for the two main study variables. 


\section{INSERT TABLE 1}

The questionnaire addressee was the IS manager of the selected firms. Unfortunately, unlike what happens in other countries, lists of managerial positions in Spain are not very complete, they don't provide the name of IT managers in most cases, as a result of which the identity of the questionnaire addressee was unknown. Table 2 offers the technical specifications of the empirical work.

\section{INSERT TABLE 2}

329 valid answers were obtained, which represents an $8 \%$ response ratio. The firms which answered the questionnaire were representative of the total population in terms of size (sales and number of employees) and sector.

\section{RESULTS AND DISCUSSION}

\section{General Characteristics of the Firms and their IS Departments}

Table 3 shows the general features of the interviewed firms, their IS departments and IS managers in the present study. They are not the focus of this study but will help to determine if the reasons and risks linked to outsourcing are perceived differently by firms, depending on these characteristics.

INSERT TABLE 3

\section{IS Outsourcing Reasons}

Taking a look at the descriptive statistics provided in Table 4, one can see that, with the exception of 'following the fashion', all the reasons proposed are regarded as 'Important' or 'Very

\footnotetext{
${ }^{2}$ These databases were edited and updated in the year 2005 .
} 
Important' determining factors for outsourcing. Especially outstanding is the advantage of being able to focus on the most strategic IS issues instead of dedicating time to routine tasks. There are also possibilities to increase IS department flexibility and, ultimately, to improve the IS services delivered by companies. At the other end, the least valued reasons were 'following the fashion' and 'technology or staff cost savings', along with 'possible alternatives to the internal IS'. In any case, despite deserving to be taken into account, the last three reasons are not the most essential factors when a decision to outsource needs to be made.

\section{INSERT TABLE 4 AND FIGURE 1}

A principal components factor analysis was carried out next using the information about the items related to IS Outsourcing reasons. The Kaiser criterion indicates the convenience of extracting three factors. A varimax rotation served to interpret the factors better. The results of this analysis appear in Table 5. The score for the item related to quality improvement has been excluded because it contributes to the same extent to the formation of two factors -1 and 3 .

\section{INSERT TABLE 5}

The first factor has been called Strategic Reasons, as it comprises the outsourcing reasons related to the possibility of focusing on strategic issues, increasing the flexibility of the department, getting rid of routine tasks, and having alternatives to IS, all of which can help to improve IS services.

The second factor is formed above all by the contribution of two items; on the one hand, that referring to the facilitation of access to technology and the reduction of the risk of technological obsolescence and, to a lesser extent, the one related to following the fashion. This factor has been given the name Technological Reasons, as these are the most influential ones here. 
The third factor has to do with cost savings, this is why it has been referred to as Economic Reasons. All three factors are equally important insofar as they contribute in the same proportion to the total variance.

\section{INSERT TABLE 6}

The possible existence of links between the said factors and the general characteristics of the firms and their IS departments can be seen in Table 6, with the following dependence associations:

- The smallest firms in the sample (in terms of sales and number of employees) see outsourcing as a way to solve technology problems and reduce costs, rather than a means to be better (it must be remembered, though, that all the firms examined in the present study fall into the category of large business organisations).

- The firms with the least staff in their IS departments also assign more value to technological and economic reasons. A possible explanation for this relation, and the previous one, referring to smallest firms, could be that firms with least economic and/or human resources see outsourcing as a way to control costs or as an alternative to improve technology, due to their own limitations. They don't arrive to see or look for more strategic achievements.

- It can be equally observed that the firms which mostly adopt outsourcing for the purpose of reducing costs are also the ones which outsource the least (with outsourcing levels below the mean).

\section{IS Outsourcing Risks}

\section{INSERT TABLE 7 AND FIGURE 2}

The observation of Table 7 and Figure 2 tells us the outsourcing risks that are regarded as the most relevant ones. The first aspect which stands out is the importance given to nearly all these 
risks with the exception of the last three. This implies the need to take into account most of these risks before facing a decision to outsource. The interviewees seem to be reluctant to outsource before the possible lack of qualification of the provider firm and its potential lack of compliance with the agreements reached. Aspects such as the excessive dependence that the client may feel with respect to the provider and the loss of knowledge that the outsourcing of services can mean for the client are also worth highlighting. On the opposite side, not too much attention seems to be assigned to the potential existence of problems in the client firm derived from its own staff's objections to outsourcing, and neither is this decision regarded as excessively risky in terms of irreversibility.

A new factor analysis has been carried out, extracting three factors (Table 8) and after a varimax rotation, an effort was made to interpret all three factors.

\section{INSERT TABLE 8}

The first factor, labelled Outsourcing Generic Risks, is formed by a large number of items (hidden costs in the contract, unclear cost benefit relationship, security issues, irreversibility of the outsourcing decision, staff issues, possible IS staff opposition), all of which turned out to be those which were least important in the previous descriptive analysis, as they refer to what interviewees consider 'not important at all'. Due to the great amount of items included in this factor, it actually explains a high proportion of the information coming from the initial variables. The second factor was given the name of Risks Derived from lack of trust on the Provider, as it has to do with the lack of qualification among the providers' staff, as well as their lack of compliance, and their possible inability to adapt to new technologies.

As for the third factor, it covers the Risks Derived from the Client, so these risks are internal to the client firms, and they relate to a fear of losing knowledge and, consequently, of having to 
depend too much on the provider. The risks derived from the provider are seen as having a greater weight or being more important than those derived from the client, which confirm the conclusions of the unidimensional analysis (Table 7), which reflects the prevalence of objections based on the provider over those linked to the client.

\section{INSERT TABLE 9}

A means difference test was carried out after obtaining these factors (Table 9), emerging the following relationships:

- Those firms which have the least sales highlight generic risks as well as risks derived from providers, especially the latter.

- Those firms which have the smallest number of workers also emphasise above all the importance of the most generic risks.

- On the contrary, those firms which outsource the most - their outsourcing level is above the mean - assign more importance to the risks derived from clients. They are over all afraid of internal risks derived from being very dependent on the provider, because if they outsource so much they can lose their skills and competences.

\section{Outsourcing Reasons and Risks: a Comparative Analysis (2001-2006)}

Finally, a comparison was drawn between the results obtained for IS Outsourcing Reasons and Risks in 2001 and in 2006. Following the advice of the experts interviewed, a new item was added for each area in 2006. The new item in the reasons area referred to the prevention of technological obsolescence. The introduction of this new item was clearly a good idea because, as seen above, although it does not appear among the most highly valued reasons, it has indeed achieved a significant degree of support among interviewees. As for the risks area, the experts pointed out that it would be convenient to include the risk of finding staff problems due to 
outsourcing. That item was not as successful as the previous one and did not rank high on the list of most highly valued risks.

The comparison of the results obtained for IS outsourcing reasons and risks in 2001 and in 2006 was based on a study of the rankings for the reasons and risks that scored the highest values in both years (Table 10).

\section{INSERT TABLE 10}

It follows from the above that the importance of reasons regarded as essential in IS Outsourcing has not varied. Reasons based on the possible improvement of IS services are the most highly valued, followed by those related to the potential improvement in technology, and in last place the same as in 2001 — those focused on cost savings. What is more, issues related to cost savings obtained a lower score in 2006 than in 2001. Probably these results could be different if the survey would be more recent. In fact, the financial and economic worldwide crisis in which we are still involved could do outsourcing an attractive option to control and cut down to technology costs (Linder, 2004).

No dramatic changes have occurred with respect to the risks regarded as the most important in 2001 and in 2006, though a subtle difference does seem to exist in their valuation. Whereas in 2001, firms associated the most relevant risks with clients (of themselves) — as they could feel an excessive dependence and suffer a loss of knowledge with respect to their providers - in 2006, the main risks had to do with providers - as there is great concern about their poor qualification level and potential lack of compliance.

\section{CONCLUSIONS}

The largest Spanish firms consider that outsourcing gives their organisations the opportunity to have better IS services and the possibility to achieve technological improvements and, although 
cost savings in staff and technology are generally seen as very important, they do not emerge as priority reasons for outsourcing in the present study. Only the smallest companies which have the fewest staff in their IS departments and outsource the least support cost savings as essential reasons to outsource.

Regarding risks, interviewees suggested that they are mainly associated with providers, with great concern being expressed about the lack of qualification among their providers' staff, the potential lack of compliance with contracts, and the inability to adapt to the new technologies. This conclusion is in tune with those obtained in previous works, according to which most of the outsourcing problems have to do with the people involved in the projects (Khan, 2007). Due to the importance of risks related with the provider side, it could be interesting as a future research to study the profitability for the clients firms of putting into practice stable and lasting outsourcing relationships with the IS providers.

No dramatic changes seem to have taken place between the opinions expressed by IS managers in 2001 and in 2006 in the Spanish entrepreneurial context. More value continues to be assigned to the improvement made possible by outsourcing, which allows the firm to have access to better IS services and more up-to-date technology, i.e. the focus is on strategic reasons which have little to do with mere cost savings. In the case of risks, whereas in the past, interviewees were above all concerned about their own weaknesses when the time came to outsource, with such fears as developing an excessive dependence on the provider or losing relevant IS knowledge items, at present an increasingly high number of firms assign more importance to the risks derived from the provider, and more precisely, to the concern about the provider's poor qualification or lack of compliance. The reason for this 'U-turn' in the valuation of these motives for concern could lie in the experience accumulated in the practice of outsourcing by client firms, which know 
increasingly well their providers, and particularly their possible weaknesses. Another reason could be the similarity of what client companies and IT providers want in their IT skills portfolio. Both of them are now looking for skills related with business domain (industry knowledge and communication). As a result the competition for talent between clients and providers could have been allowed the entry of IT providers with a deficit of quality and professionalism.

Many of the reasons and risks mentioned in this study are difficult to measure, although it is worth making the effort to list and value them so that they can be taken into account and serve as a guide for managers in future outsourcing processes. Although the methodology used in the paper is mainly descriptive, an important contribution made by this study is not only the specification of outsourcing reasons and risks but also the fact that they are considered important by the firms interviewed. Additionally, being able to draw a comparison about the reality of outsourcing within this five-year horizon makes it possible to identify certain trends.

Most of the literature has studied outsourcing reasons and risks from the point of view of the client, however, the increasing dynamism of the outsourcing market means that a significant proportion of the risks and responsibilities associated with outsourcing are going to fall upon the provider. This is actually a limitation of the study that can be overcome by carrying out new analyses from the perspective of the provider of these services.

\section{REFERENCES}

Alner, M. (2001) “The Effects of Outsourcing on Information Security”, Information Systems Security, Vol. 10 No. 2 , pp. 35-43.

Ang, S. and Straub, D. (1998) "Production and Transaction Economies and IS Outsourcing: A Study of the U.S. Bank Industry”, MIS Quarterly, Vol. 22 No. 4, pp. 535-552.

Bahli, B. and Rivard, S. (2005) "Validating Measures of Information Technology Outsourcing Risks Factors", Omega. Vol. 33 No 2, pp. 175-187.

Baldwing, LP; Irani, Z. and Love, P. (2001) "Outsourcing Information Systems: Drawing Lessons from a Banking Case Study”, European Journal of Information Systems, Vol. 10 No. 1, pp. 15-24.

Barthélemy, J. (2001) “The Hidden Cost of IT Outsourcing”, MIT Sloan Management Review, Vol. 42 No. 3, pp. 60-69. Clark, T.D.; Zmud, R.W. and McCray, G.E. (1995) "The Outsourcing of Information Services: Transforming the Nature of Business in the Information Industry", Journal of Information Technology, Vol. 10, pp. 221-237. 
Claver, E.; Gonzalez, R.; Gasco, J. and Llopis, J. (2002) “Information Systems Outsourcing: Reasons, Reservations and Success Factors", Logistics Information Management, Vol. 15 No. 4, pp. 294-308.

Computerworld (2009). "El RACC confía a IBM la gestión de su infraestructura tecnológica", Internet Document, download, 1/9/2009. http://www.idg.es/computerworld

Earl, M.J. (1996) “The Risk of Outsourcing IT”, Sloan Management Review, Vol. 37 No. 3, pp. 26-32.

Fink, D. (1994) “A Security Framework for Information Systems Outsourcing”, Information Management \& Computer Security, Vol. 2 No. 4, pp. 3-8.

Fowler, A. and Jeffs, B. (1998) "Examining Information Systems Outsourcing: A Case Study from The United Kingdom", Journal of Information Technology, Vol. 13 No. 2, pp. 111-126.

Glass, R.L. (1996) “The End of the Outsourcing Era”, Information Systems Management, Vol. 13 No. 2, pp. 89-91.

Gonzalez, R.; Gasco, J. and Llopis, J. (2005a) "Information Systems Outsourcing Reasons in the Largest Spanish Firms", International Journal of Information Management, Vol. 25 No. 2, pp. 117-136.

Gonzalez, R.; Gasco, J and Llopis, J. (2005b) "Information Systems Outsourcing Risks: a Study of Large Firms", Industrial Management \& Data Systems, Vol. 105 No. 1, pp. 45-62.

Grover, V.; Cheon, M.J. and Teng, T.C. (1994) "A Descriptive Study on the Outsourcing of Information Systems Functions", Information \& Management, Vol. 27 No. 1, pp. 33-44.

Grover, V.; Cheon, M.J. and Teng, T.C. (1996) "The Effect of Service Quality and Partnership on the Outsourcing of Information Systems Functions", Journal of Management Information Systems, Vol. 12 No. 4, pp. 89-116.

Gupta, G. and Gupta, H. (1992) "Outsourcing the IS function. Is it necessary for your organization?", Information Systems Management, Vol. 9 No. 3, pp. 44-50.

Guterl, F. (1996) "How to Manage your Outsourcer?", Datamation, Vol. 42 No. 5, pp. 79-83.

Hayes, D.C.; Hunton, J.E. and Reck, J.J. (2000) "Information Systems Outsourcing Announcements: Investigating the Impact on the Market Value of Contract-Granting Firms", Journal of Information Systems, Vol. 14 No. 2, pp. 109-125.

Hurst, I. and Hanessian, B.G. (1995) “Navigating IT Channels: Integrate or Outsource?”, The McKinsey Quarterly, No. 3 , pp. 103-110.

IBM (2008) "El RACC elige a IBM para gestionar su infraestructura tecnológica", Internet document, download 3/9/2009. http://www-03.ibm.com/press/es/es/pressrelease/26280.wss

IBM (2009) "ENDESA unifica la gestión de sus sistemas de información en España y Latinoamérica", Internet document, download 8/9/2009. http://www-03.ibm.com/press/es/es/pressrelease/26562.wss

IDATE Foundation (2005) "Digiworld 2005. Los retos del mundo digital" IDATE-ENTER, Montpellier, France. Internet Document. http://enter.es/enter/file/espanol/texto/digiworld.2005.pdf

Jurison, J. (1995) “The Role of Risk and Return in Information Technology Outsourcing Decisions", Journal of Information Technology, Vol. 10 No. 4, pp. 239-247.

Khan, I. (2007) "Outsourcing Not Slowing Down: Study", Internet Document, download 13/12/2007. http://www.ddj.com/architect/197005853?cid=RSSfeed_DDJ_All

KPMG (2007) "Strategic Evolution. A Global Survey on Sourcing Today". Internet Document. http://www.kpmg.com.au/Portals/0/rasita_strategic-evolution200701.pdf

Lacity, M. and Hirschheim, R. (1993a) "Implementing Information Systems Outsourcing: Key Issues and Experiences of an Early Adopter", Journal of General Management, Vol. 19 No. 1, pp. 17-31.

Lacity, M. and Hirschheim, R. (1993b) “The Information Systems Outsourcing Bandwagon", Sloan Management Review, Vol. 35 No. 1, pp. 73-86.

Lacity, M.; Hirschheim, R. and Willcocks, L. (1994) "Realizing Outsourcing Expectations. Incredible Expectations, Credible Outcomes", Information Systems Management, Vol. 11 No. 4, pp. 7-18.

Lee, J-N.; Huynh, M.Q. and Hirschheim, R. (2008) "An integrative model of trust on IT outsourcing: Examining a bilateral perspective”, Information Systems Frontiers, Vol. 10 No. 2, pp. 145-163.

Linder, J.C. (2004) “Transformational Outsourcing”, MIT Sloan Management Review, Vol. 45 No. 2, pp. 52-58.

Loh, L. and Venkatraman, N. (1992) "Diffusion of information technology outsourcing: influence sources and the Kodak effect”. Information Systems Research, Vol. 3 No. 4, pp. 334-358.

Martinsons, M.G. (1993) "Outsourcing Information Systems: A Strategic Partnership with Risk", Long Range Planning, Vol. 26 No. 3, pp. 18-25.

McFarlan, F.W. and Nolan, R.L. (1995) "How to Manage an IT Outsourcing Alliance", Sloan Management Review, Vol. 36 No. 2, pp. 8-23.

McLellan, K.; Marcolin, B. and Beamish, P. (1995) "Financial and Strategic Motivations behind IS Outsourcing", Journal of Information Technology, Vol. 10 No. 4, pp. 299-321.

Olson, D.L. (2007) "Evaluation of ERP Outsourcing", Computers \& Operation Research, Vol. 34 No. 12, pp. 37153724 . 
Palvia, P.C. (1995) “A Dialectic View of Information Systems Outsourcing: Pros and Cons", Information \& Management, Vol. 29 No. 5, pp. 265-275.

Poppo, L. and Zenger, T. (1998) "Testing alternative theories of the firm: transaction cost, knowledge-based, and measurement explanations for make-or-buy decisions in information services", Strategic Management Journal, Vol. 19 No. 9, pp.853-877.

Slaughter, S. and Ang, S. (1996) "Employment Outsourcing in Information Systems", Communications of the ACM, Vol. 39 No. 7, pp. 47-54.

Smith, M.A.; Mitra, S. and Narasimhan, S. (1998) "Information Systems Outsourcing: A Study of Pre-Event Firm Characteristics", Journal of Management Information Systems, Vol. 15 No. 2, pp. 61-93.

Tafti, M.H.A. (2005) "Risk factors associated with offshore IT outsourcing", Industrial Management \& Data Systems, Vol. 105 No. 5, pp. 549-560.

Takahashi, S. and Sayer, P. (2007) "European IT/Telecom Converged Service Delivery Outsourcing Deals: H1 2006.

The Battle Rages Between IT And Telecom Service Providers". Internet document, downdolad 3/2/2008. http://www.forrester.com/rb/search/results.jsp? $\mathrm{No}=25 \& \mathrm{~N}=50174$

Techweek (2009a) "Endesa confía la gestión de sus TI a IBM", Internet document, download 1/9/2009. http://www.techweek.es/outsourcing/soluciones-negocio/1005426004401

Techweek (2009b) "Caixa Galicia firma un contrato con BT por 26 millones de euros", Internet document, download 1/9/2009. http://www.techweek.es/outsourcing/noticias/1005679004401

Techweek (2009c) "HP gestionará la plataforma TI de Renfe", Internet document, download 4/8/2009. http://techweek.es/outsourcing/noticias/1005342004401

Udo, G.G. (2000), "Using analytic hierarchy process to analyse the information technology outsourcing decision". Industrial Management \& Data Systems, Vol. 100 No. 9, pp.421-9.

Whitten, D. and Wakefield, R.L. (2006) "Measuring Switching Costs in IT Outsourcing Services", Journal of Strategic Information Systems, Vol. 15, pp. 219-248.

Willcocks, L.; Feeny, D. and Olson, N. (2006) "Implementing Core IS Capabilities: Feeny-Willcocks IT Governance and Management Framework Revisited”, European Management Journal, Vol. 24 No. 1, pp. 28-37.

Willcocks, L.P. and Fitzgerald, G. (1996) "IT Outsourcing and the Changing Shape of the Information Systems Function", in: Earl, M.J. (Ed.), Information Management. The Organizational Dimension, Oxford University Press, Oxford, pp. 270-294.

Willcocks, L.P., Lacity, M.C. and Fitzgerald, G. (1995) "Information Technology Outsourcing in Europe and the USA: Assessment Issues”, International Journal of Information Management, Vol. 15 No. 5, pp. 333-351.

Willcocks, L.P., Lacity, M.C. and Kern, T. (1999) "Risk Mitigation in IT Outsourcing Strategy Revisited: Longitudinal Case Research at LISA", Journal of Strategic Information Systems, Vol. 8 No. 3, pp. 285-314.

ZDNet (2007) "87\% of Outsourcing Buyers to Continue Outsourcing", Internet Document, download 4/4/2008. http://blogs.zdnet.com/ITFacts/index.php?cat=29 
Table 1: Measures of variables and reliability

\begin{tabular}{|c|c|c|c|}
\hline Construct & Source & Measure & $\begin{array}{c}\text { Reliability } \\
\text { (Cronbach's } \alpha \text { ) }\end{array}$ \\
\hline $\begin{array}{c}\text { IS } \\
\text { Outsourcing } \\
\text { Reasons }\end{array}$ & $\begin{array}{l}\text { Ang and Straub, 1998; Baldwing, Irani and Love, 2001; } \\
\text { Clarck, Zmud and McCray, 1995; Grover, Cheon and } \\
\text { Teng, 1996; Gupta and Gupta, 1992; Hayes, Hunton and } \\
\text { Reck, 2000; Jurison, 1995; Lacity and Hirschheim, } \\
\text { 1993a-1993b; Loh and Venkatraman, 1992, McLellan, } \\
\text { Marcolin and Beamish, 1995; McFarlan and Nolan, } \\
\text { 1995; Slaughter and An, 1996; Udo, 2000; } 2001 \text { year } \\
\text { questionnaire and own materials }\end{array}$ & $\begin{array}{c}10 \text { Items } \\
\text { measured with } \\
\text { a 1-to-7 Likert } \\
\text { scale }\end{array}$ & 0.801 \\
\hline $\begin{array}{c}\text { IS } \\
\text { Outsourcing } \\
\text { Risks }\end{array}$ & $\begin{array}{l}\text { Bahli and Rivard, 2005; Barthélemy, 2001; Earl, 1996; } \\
\text { Fink, 1994; Fowler and Jeffs, 1998; Glass, 1996; Guterl, } \\
\text { 1996; Hurst and Hanessian, 1995; Jurison, 1995; Lacity } \\
\text { and Hirschheim, 1993b; Martinson, 1993; Palvia, 1995; } \\
\text { Willcocks and Lacity, 1999; Willcocks and Fitzgerald, } \\
\text { 1996; Willcokcs, Lacity and Kern, 1999; } 2001 \text { year } \\
\text { questionnaire and own materials }\end{array}$ & $\begin{array}{c}11 \text { Items } \\
\text { measured with } \\
\text { a 1-to-7 Likert } \\
\text { scale }\end{array}$ & 0.818 \\
\hline
\end{tabular}

Table 2: Study technical specifications

\begin{tabular}{|l|l|}
\hline Scope & Spain \\
Population & 4,107 largest Spanish business (by sales) \\
Sample size & 329 valid answers $(8.01 \%)$ \\
Sampling error & $5 \%$ \\
Survey date & September-December, 2006 \\
\hline
\end{tabular}


Table 3: General Characteristics of the Firms

\begin{tabular}{|c|c|c|c|}
\hline & & $\mathrm{N}$ & $\%$ \\
\hline \multirow{2}{*}{$\begin{array}{c}\text { National } \\
\text { Outsourcing }\end{array}$} & No & 54 & 16.4 \\
\hline & Yes & 275 & 83.6 \\
\hline \multirow{2}{*}{$\begin{array}{c}\text { Global } \\
\text { Outsourcing }\end{array}$} & No & 275 & 83.6 \\
\hline & Yes & 54 & 16.4 \\
\hline \multirow{2}{*}{$\begin{array}{c}\text { Outsourcing } \\
\text { level }\end{array}$} & Below the mean & 165 & 50.2 \\
\hline & Above the mean & 164 & 49.8 \\
\hline \multirow{4}{*}{ Staff } & $0-50$ & 28 & 8.5 \\
\hline & $51-500$ & 218 & 66.2 \\
\hline & More than 500 & 76 & 23.1 \\
\hline & Lost & 7 & 2.1 \\
\hline \multirow{5}{*}{$\begin{array}{c}\text { Sales } \\
(\text { million } €)\end{array}$} & Up to 30 & 31 & 9.4 \\
\hline & Between 31 and 60 & 146 & 44.3 \\
\hline & Between 61 and 300 & 129 & 39.2 \\
\hline & Above 300 & 16 & 4.9 \\
\hline & Lost & 7 & 2.1 \\
\hline \multirow{3}{*}{ Sector } & Industry & 189 & 57.4 \\
\hline & Services & 102 & 31.0 \\
\hline & Intensive IT Services & 38 & 11.6 \\
\hline \multirow{4}{*}{ IS Staff } & 1-10 Workers & 250 & 76.0 \\
\hline & 11-100 Workers & 66 & 20.1 \\
\hline & 101-250 Workers & 6 & 1.8 \\
\hline & Lost & 7 & 2.1 \\
\hline \multirow{4}{*}{$\begin{array}{c}\text { Budget } \\
\text { percentage } \\
\text { allocated to IS }\end{array}$} & $0-4$ & 138 & 41.9 \\
\hline & $5-10$ & 56 & 17.0 \\
\hline & $11-56$ & 13 & 4 \\
\hline & Lost & 122 & 37.1 \\
\hline
\end{tabular}

Table 4: Outsourcing Reasons

$\begin{array}{lllllllll}\text { Not important at all } & 1 & 2 & 3 & 4 & 5 & 6 & 7 & \text { Very important }\end{array}$

\begin{tabular}{|l|c|c|c|}
\hline & Mean & Median & Mode \\
\hline Focus on Strategic Issues & 6.03 & 6 & 7 \\
Increased IS Department Flexibility & 5.37 & 6 & 7 \\
Improved IS Quality & 5.11 & 5 & 7 \\
Elimination of Troublesome, Everyday Problems & 4.88 & 5 & 7 \\
Increased Access to Technology & 4.78 & 5 & 6 \\
Decreased Obsolescence Risk & 4.66 & 5 & 7 \\
Staff Cost Savings & 4.34 & 5 & 6 \\
Providing Alternatives to in-house IS & 4.19 & 4 & 5 \\
Technology Cost Savings & 4.04 & 4 & 5 \\
Following the Fashion & 1.67 & 1 & 1 \\
\hline
\end{tabular}


Table 5: Total Variance Explained and Rotated Component Matrix in Factor Reasons

\begin{tabular}{|c|c|c|c|c|c|c|c|c|c|c|}
\hline \multicolumn{7}{|c|}{ Total Variance Explained } & \multicolumn{4}{|c|}{ Rotated Component Matrix } \\
\hline & \multicolumn{3}{|c|}{ Initial Eigenvalues } & \multicolumn{3}{|c|}{ Rotation Sum of Squared Loadings } & \multirow[t]{2}{*}{ Variable } & \multicolumn{3}{|c|}{ Component } \\
\hline Component & Total & $\begin{array}{c}\% \text { of } \\
\text { Variance }\end{array}$ & $\begin{array}{c}\text { Cumulative } \\
\%\end{array}$ & Total & $\begin{array}{c}\% \text { of } \\
\text { Variance }\end{array}$ & Cumulative $\%$ & & 1 & 2 & 3 \\
\hline 1 & 3.670 & 36.700 & 36.700 & 2.078 & 20.784 & 20.784 & Focus on Strategic Issues & 0.805 & & \\
\hline 2 & 1.388 & 13.884 & 50.584 & 2.021 & 20.208 & 40.992 & Increased IS Depart. Flexi. & 0.564 & & \\
\hline 3 & 1.061 & 10.609 & 61.193 & 2.020 & 20.200 & 61.193 & Elimin. Trouble. Problem & 0.789 & & \\
\hline 4 & 0.976 & 9.755 & 70.948 & & & & Access to Technology & & 0.826 & \\
\hline 5 & 0.794 & 7.944 & 78.892 & & & & Decreased Obsolesc. Risk & & 0.803 & \\
\hline 6 & 0.642 & 6.418 & 58.310 & & & & Staff Cost Savings & & & 0.900 \\
\hline 7 & 0.474 & 4.743 & 90.054 & & & & Providing Alternatives & 0.427 & & \\
\hline 8 & 0.416 & 4.165 & 94.218 & & & & Technology Cost Savings & & & 0.825 \\
\hline 9 & 0.297 & 2.969 & 97.187 & & & & Following the Fashion & & 0.446 & \\
\hline 10 & 0.281 & 2.813 & 100.000 & & & & & & & \\
\hline
\end{tabular}

Table 6: Equality of Means Test (Reasons)

\begin{tabular}{|c|c|c|c|c|c|c|}
\hline & & & \multicolumn{2}{|c|}{ Levene } & \multirow[b]{2}{*}{$\mathrm{T}$ (student) } & \multirow[b]{2}{*}{ Sign. } \\
\hline & Sales (million $€$ ) & Mean & $\mathrm{F}$ & Sign. & & \\
\hline Factor 1: Strategic Reasons & $\begin{array}{l}\text { Up to } 90 \\
\text { More than } 90\end{array}$ & $\begin{array}{c}0.120 \\
-0.177 \\
\end{array}$ & 0.006 & 0.939 & 2.446 & 0.015 \\
\hline Factor 2: Technology Reasons & $\begin{array}{l}\text { Up to } 90 \\
\text { More than } 90\end{array}$ & $\begin{array}{c}0.274 \\
-0.402\end{array}$ & 0.800 & 0.372 & 5.826 & 0.000 \\
\hline \multirow[t]{2}{*}{ Factor 3: Economic Reasons } & $\begin{array}{l}\text { Up to } 90 \\
\text { More than } 90\end{array}$ & $\begin{array}{r}0.248 \\
-0.365 \\
\end{array}$ & 0.142 & 0.707 & 5.229 & 0.000 \\
\hline & Staff (people) & & & & & \\
\hline Factor 1: Strategic Reasons & $\begin{array}{l}\text { Up to } 500 \\
\text { More than } 500\end{array}$ & $\begin{array}{c}0.015 \\
-0.042 \\
\end{array}$ & 1.374 & 0.242 & 0.423 & 0.673 \\
\hline Factor 2: Technology Reasons & $\begin{array}{l}\text { Up to } 500 \\
\text { More than } 500\end{array}$ & $\begin{array}{r}0.862 \\
-0.233 \\
\end{array}$ & 0.480 & 0.489 & 2.368 & 0.019 \\
\hline \multirow[t]{2}{*}{ Factor 3: Economic Reasons } & $\begin{array}{l}\text { Up to } 500 \\
\text { More than } 500\end{array}$ & $\begin{array}{r}0.126 \\
-0.342 \\
\end{array}$ & 0.000 & 0.994 & 3.515 & 0.001 \\
\hline & IS Staff & & & & & \\
\hline Factor 1: Strategic Reasons & $\begin{array}{l}\text { Below the mean } \\
\text { Above the mean }\end{array}$ & $\begin{array}{c}0.076 \\
-0.084\end{array}$ & 2.245 & 0.135 & 1.329 & 0.185 \\
\hline Factor 2: Technology Reasons & $\begin{array}{l}\text { Below the mean } \\
\text { Above the mean }\end{array}$ & $\begin{array}{c}0.201 \\
-0.223 \\
\end{array}$ & 0.579 & 0.447 & 3.593 & 0.000 \\
\hline \multirow[t]{2}{*}{ Factor 3: Economic Reasons } & $\begin{array}{l}\text { Below the mean } \\
\text { Above the mean }\end{array}$ & $\begin{array}{c}0.188 \\
-0.208 \\
\end{array}$ & 1.127 & 0.289 & 3.343 & 0.001 \\
\hline & $\begin{array}{l}\text { Outsourcing } \\
\text { Level }\end{array}$ & & & & & \\
\hline Factor 1: Strategic Reasons & $\begin{array}{l}\text { Below the mean } \\
\text { Above the mean }\end{array}$ & $\begin{array}{l}-0.109 \\
0.086 \\
\end{array}$ & 0.423 & 0.516 & -1.623 & 0.106 \\
\hline Factor 2: Technology Reasons & $\begin{array}{l}\text { Below the mean } \\
\text { Above the mean }\end{array}$ & $\begin{array}{r}0.016 \\
-0.013 \\
\end{array}$ & 0.033 & 0.855 & 0.249 & 0.803 \\
\hline Factor 3: Economic Reasons & $\begin{array}{l}\text { Below the mean } \\
\text { Above the mean }\end{array}$ & $\begin{array}{c}0.112 \\
-0.088 \\
\end{array}$ & 1.223 & 0.270 & 1.657 & $0.099 *$ \\
\hline
\end{tabular}

*Significance level 9.9\% 
Table 7: Outsourcing Risks

$\begin{array}{lllllllll}\text { Not important at all } & 1 & 2 & 3 & 4 & 5 & 6 & 7 & \text { Very important }\end{array}$

\begin{tabular}{|l|c|c|c|}
\hline & Mean & Median & Mode \\
\hline Provider staff qualification & 6.56 & 7 & 7 \\
The provider does not comply with the contract & 6.27 & 7 & 7 \\
An excessive dependence on the provider & 5.45 & 6 & 6 \\
Loss of critical skills and competences & 4.93 & 5 & 6 \\
Inability to adapt to new technologies & 4.67 & 5 & 5 \\
Hidden costs in the contract & 4.52 & 5 & 6 \\
Unclear cost-benefit relationship & 4.47 & 5 & 5 \\
Security issues & 4.08 & 4 & 4 \\
Irreversibility of the outsourcing decision & 3.68 & 3 & 2 \\
Staff issues & 2.55 & 2 & 2 \\
Possible IS staff opposition & 2.48 & 1 & 1 \\
\hline
\end{tabular}

Table 8: Total Variance Explained and Rotated Component Matrix in Factor Risks

\begin{tabular}{|c|c|c|c|c|c|c|c|c|c|c|}
\hline \multicolumn{7}{|c|}{ Total Variance Explained } & \multicolumn{4}{|c|}{ Rotated Component Matrix } \\
\hline & \multicolumn{3}{|c|}{ Initial Eigenvalues } & \multicolumn{3}{|c|}{ Rotation Sum of Squared Loadings } & \multirow[t]{2}{*}{ Variable } & \multicolumn{3}{|c|}{ Component } \\
\hline Component & Total & $\begin{array}{c}\% \text { of } \\
\text { Variance }\end{array}$ & $\begin{array}{c}\text { Cumulative } \\
\%\end{array}$ & Total & $\begin{array}{c}\% \text { of } \\
\text { Variance }\end{array}$ & Cumulative $\%$ & & 1 & 2 & 3 \\
\hline 1 & 4.093 & 37.208 & 37.208 & 3.123 & 28.393 & 28.393 & Qualific. of the provider's staff & & 0.717 & \\
\hline 2 & 1.508 & 13.712 & 50.921 & 2.148 & 19.523 & 47.915 & The provider does not comply & & 0.745 & \\
\hline 3 & 1.161 & 10.554 & 61.475 & 1.492 & 13.560 & 61.475 & An excessive dependence & & & 0.815 \\
\hline 4 & 0.889 & 8.085 & 69.561 & & & & Loss of skills and competences & & & 0.630 \\
\hline 5 & 0.729 & 6.632 & 76.192 & & & & Inability to adapt to new techn. & & 0.821 & \\
\hline 6 & 0.663 & 6.024 & 82.216 & & & & Hidden costs in the contract & 0.578 & & \\
\hline 7 & 0.584 & 5.307 & 87.523 & & & & Unclear cost-benefit relation. & 0.568 & & \\
\hline 8 & 0.486 & 4.422 & 91.945 & & & & Security issues & 0.571 & & \\
\hline 9 & 0.382 & 3.471 & 95.417 & & & & Irreversibility of the decision & 0.650 & & \\
\hline 10 & 0.295 & 2.682 & 98.099 & & & & Staff issues & 0.874 & & \\
\hline 11 & 0.209 & 1.901 & 100.000 & & & & Possible IS staff opposition & 0.846 & & \\
\hline
\end{tabular}


Table 9: Equality of Means Test (Risks)

\begin{tabular}{|c|c|c|c|c|c|c|}
\hline & & & \multicolumn{2}{|c|}{ Levene } & \multirow[b]{2}{*}{$\begin{array}{c}\text { T student or } \\
\text { Mann-Whitney's } \\
\text { U test }\end{array}$} & \multirow[b]{2}{*}{ Sign. } \\
\hline & Sales (million $€$ ) & Mean & $\mathrm{F}$ & Sign. & & \\
\hline Factor 1: General Risks & $\begin{array}{l}\text { Up to } 90 \\
\text { More than } 90\end{array}$ & $\begin{array}{r}0.115 \\
-0.169 \\
\end{array}$ & 3.214 & 0.074 & $2.234(\mathrm{~T})$ & 0.026 \\
\hline Factor 2: Providers' Risks & $\begin{array}{l}\text { Up to } 90 \\
\text { More than } 90\end{array}$ & $\begin{array}{c}0.196 \\
-0.289\end{array}$ & 22.015 & 0.000 & $5947.0(\mathrm{U})$ & 0.003 \\
\hline Factor 3: Clients' Risks & $\begin{array}{l}\text { Up to } 90 \\
\text { More than } 90\end{array}$ & $\begin{array}{c}-0.000 \\
0.000 \\
\end{array}$ & 0.047 & 0.828 & $-0.013(\mathrm{~T})$ & 0.990 \\
\hline & Staff (people) & & & & & \\
\hline Factor 1: General Risks & $\begin{array}{l}\text { Up to } 500 \\
\text { More than } 500\end{array}$ & $\begin{array}{c}0.076 \\
-0.210 \\
\end{array}$ & 1.071 & 0.302 & $2.022(\mathrm{~T})$ & 0.044 \\
\hline Factor 2: Providers' Risks & $\begin{array}{l}\text { Up to } 500 \\
\text { More than } 500\end{array}$ & $\begin{array}{c}0.050 \\
-0.138 \\
\end{array}$ & 1.181 & 0.278 & $1.322(\mathrm{~T})$ & 0.187 \\
\hline Factor 3: Clients' Risks & $\begin{array}{l}\text { Up to } 500 \\
\text { More than } 500\end{array}$ & $\begin{array}{c}-0.014 \\
0.039 \\
\end{array}$ & 0.013 & 0.909 & $-0.375(\mathrm{~T})$ & 0.708 \\
\hline & $\begin{array}{l}\text { Outsourcing } \\
\text { Level }\end{array}$ & & & & & \\
\hline Factor 1: General Risks & $\begin{array}{l}\text { Below the mean } \\
\text { Above the mean }\end{array}$ & $\begin{array}{c}0.105 \\
-0.074 \\
\end{array}$ & 0.225 & 0.635 & $1.405(\mathrm{~T})$ & 0.161 \\
\hline Factor 2: Providers' Risks & $\begin{array}{l}\text { Below the mean } \\
\text { Above the mean }\end{array}$ & $\begin{array}{r}-0.045 \\
0.032 \\
\end{array}$ & 0.250 & 0.617 & $-0.611(\mathrm{~T})$ & 0.542 \\
\hline Factor 3: Clients' Risks & $\begin{array}{l}\text { Below the mean } \\
\text { Above the mean }\end{array}$ & $\begin{array}{c}-0.173 \\
0.121\end{array}$ & 0.108 & 0.743 & $-2.327(\mathrm{~T})$ & 0.021 \\
\hline
\end{tabular}

Table 10: Outsourcing Reasons and Risks (2001-2006)

\begin{tabular}{|c|c|c|c|c|c|}
\hline \multicolumn{3}{|c|}{ Reasons } & \multicolumn{3}{|l|}{ Risks } \\
\hline & $\begin{array}{c}2006 \\
\text { Ranking }\end{array}$ & $\begin{array}{c}2001 \\
\text { Ranking }\end{array}$ & & $\begin{array}{c}2006 \\
\text { Ranking }\end{array}$ & $\begin{array}{c}2001 \\
\text { Ranking }\end{array}$ \\
\hline Focus on strategic issues & $1 \mathrm{st}$ & $1 \mathrm{st}$ & Provider staff qualification & $1 \mathrm{st}$ & 3rd \\
\hline Increased IS dep. Flexibility & 2nd & 2nd & The provider does not comply & 2nd & 4 th \\
\hline Improved IS quality & $3 \mathrm{rd}$ & $3 \mathrm{rd}$ & An excessive dependence & $3 \mathrm{rd}$ & $1 \mathrm{st}$ \\
\hline Elimin. troublesome problems & 4 th & 4th & Loss of skills and competences & 4 th & 2nd \\
\hline Increased access to technology & 5 th & 6th & Inability to adapt to new techn. & 5 th & 10th \\
\hline Decreased obsolesc. risk & 6 th & - & Hidden costs in the contract & 6 th & 6 th \\
\hline Staff cost saving & 7 th & 5 th & Unclear cost-benefit relation & 7 th & 5 th \\
\hline Alternatives to in-house IS & 8th & 8th & Security issues & 8th & 7 th \\
\hline Technology cost saving & 9th & 7 th & Irreversibility of the decision & 9th & 8 th \\
\hline Following the fashion & 10th & 9th & Staff issues & 10th & - \\
\hline & & & Possible IS staff opposition & 11 th & 9th \\
\hline
\end{tabular}


Figure 1: Outsourcing Reasons (2006)

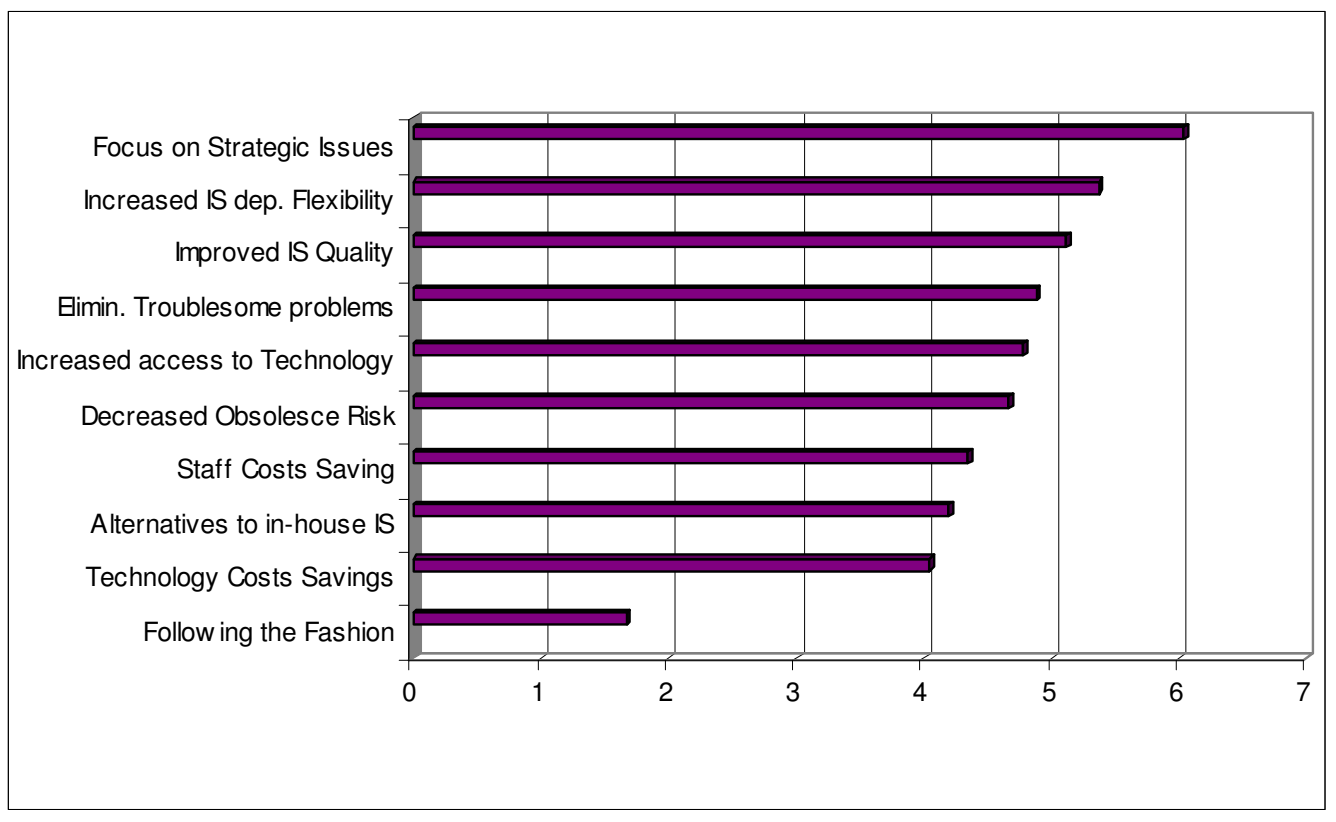

Figure 2: Outsourcing Risks (2006)

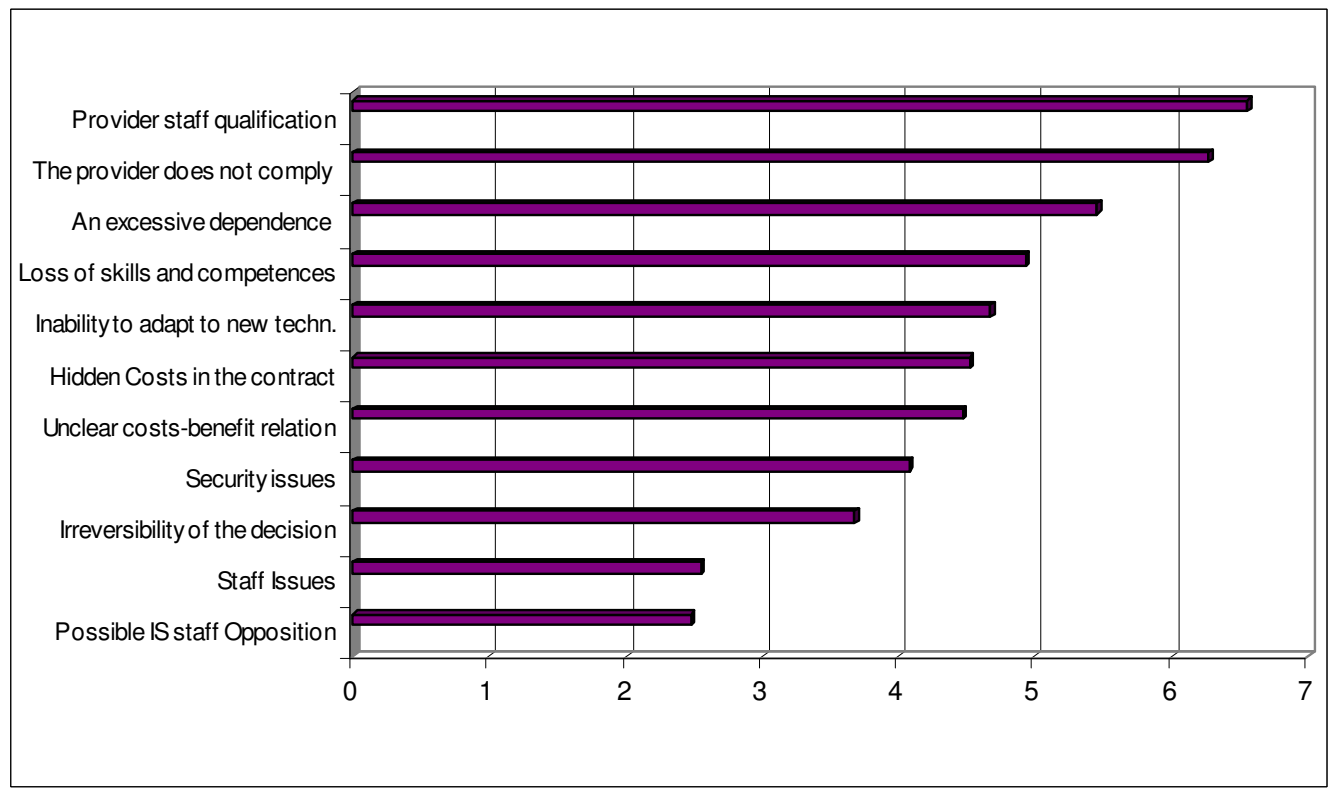

